\title{
Fluids, Metals, and Mineral/Ore Deposits
}

\author{
Xing Ding $\mathbb{D}^{1,2}$ Daniel E. Harlov, ${ }^{3,4}$ Bin Chen, ${ }^{5}$ and Weidong Sun ${ }^{2,6,7}$ \\ ${ }^{1}$ State Key Laboratory of Isotope Geochemistry, Guangzhou Institute of Geochemistry, Chinese Academy of Sciences, Guangzhou, China \\ ${ }^{2}$ CAS Center for Excellence in Tibetan Plateau Earth Sciences, Chinese Academy of Sciences, Beijing, China \\ ${ }^{3}$ GeoforschungsZentrum, Telegrafenberg, 14473 Potsdam, Germany \\ ${ }^{4}$ Department of Geology, University of Johannesburg, P.O. Box 524, Auckland Park 2006, South Africa \\ ${ }^{5}$ Hawaii Institute of Geophysics and Planetology, University of Hawaii at Manoa, Honolulu, HI, USA \\ ${ }^{6}$ Center of Deep Sea Research, Institute of Oceanography, Chinese Academy of Sciences, Qingdao, China \\ ${ }^{7}$ Laboratory for Marine Mineral Resources, Qingdao National Laboratory for Marine Science and Technology, Qingdao, China
}

Correspondence should be addressed to Xing Ding; xding@gig.ac.cn

Received 31 January 2018; Accepted 1 March 2018; Published 3 April 2018

Copyright (C) 2018 Xing Ding et al. This is an open access article distributed under the Creative Commons Attribution License, which permits unrestricted use, distribution, and reproduction in any medium, provided the original work is properly cited.

\section{Introduction}

Hydrothermal mineralization is one of the primary oreforming processes on Earth, existing widely not only in extensional tectonic settings, for example, continental or oceanic rifts, but also in compressional ones, such as subduction zones and collisional orogenic belts [1]. Traditionally, studies on fluid-rock interaction [2,3], fluid inclusions [4$6]$, element partitioning $[7,8]$, element or mineral solubility [9-12], and aqueous metal speciation [13, 14] have provided abundant information on hydrothermal ore-forming processes. As a result, many thermodynamic properties for important metals in aqueous solutions under hydrothermal conditions, as well as their geochemical behavior, have been effectively determined through empirical and semiempirical extrapolation methods $[15,16]$. These studies have further enriched our views on dissolution, speciation, migration, and precipitation of metals during hydrothermal processes and also improved our understanding of the formation of important metal deposits.

\section{Problems and Challenges}

Knowledge of the dissolution, transport, and deposition of ore-forming metals at elevated temperatures and pressures is a requisite for an unambiguous understanding of hydrothermal mineralization processes and metal deposit formation.
As seen in Figure 1, it is usually considered that ore-forming metals are extracted from the source into the fluids and transported in the form of stable complexes to the deposit site. During this process, the interaction between fluids and wall rocks, as well as the changes in environmental conditions such as temperature, pressure, oxygen fugacity, and $\mathrm{pH}$, can significantly influence the chemical states of the fluids and metals. Though considerable efforts have been made to enhance our understanding of this process $[1,16]$, a few important problems remain to be solved as outlined below.

2.1. Properties of Ore-Forming Metal Complex. It is well known that ore-forming metals in hydrothermal fluids migrate mainly in the form of metal complexes [16]. Thus the properties of ore-forming aqueous metal complexes play a crucial role in controlling metal mobility and mineral deposition.

Extraction of ore-forming metal ions from the source is usually accompanied by metal speciation and complexation (Figure 1). Theoretically, the dissolution and consequent complexation of metal are achieved by the solvation, hydrolysis, and nucleophilic substitution reactions $[15,17]$. A general solvation reaction for an ore-forming metal ion $M$ can be described as

$$
\mathrm{M}^{Z+}+n \mathrm{H}_{2} \mathrm{O} \Longleftrightarrow\left[\mathrm{M}\left(\mathrm{H}_{2} \mathrm{O}\right)_{n}\right]^{Z+}
$$




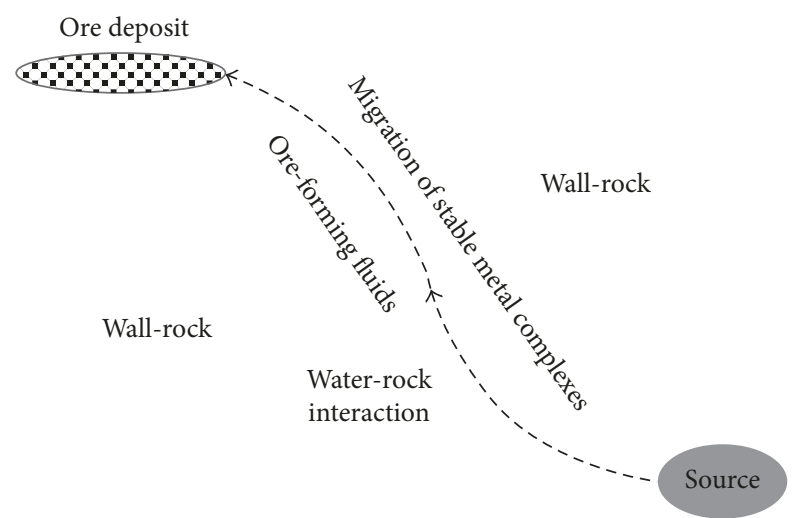

FIGURE 1: Sketch on the forming process of hydrothermal ore deposit.

Because of high instability, the solvated metal complexes easily hydrolyze into hydroxy ones by a proton loss, taking the following form:

$$
\left[\mathrm{M}\left(\mathrm{H}_{2} \mathrm{O}\right)_{n}\right]^{Z+} \Longleftrightarrow\left[\mathrm{M}(\mathrm{OH})_{n}\right]^{(Z-n)}+n \mathrm{H}^{+}
$$

When a certain anion solvent $\mathrm{X}$ enters the fluids, more complicated speciation will occur according to

$$
\left[\mathrm{M}(\mathrm{OH})_{n}\right]^{(\mathrm{Z}-n)}+(n-1) \mathrm{X}^{-} \Longleftrightarrow\left[\mathrm{M}(\mathrm{OH}) \mathrm{X}_{n-1}\right]^{\mathrm{Z}-n}+(n-1) \mathrm{OH}^{-}
$$

This reaction can be considered as a nucleophilic substitution of a hydroxyl $\mathrm{OH}^{-}$by the anion $\mathrm{X}^{-}$.

Because the natural hydrothermal fluids generally comprise enormous ion and anion and volatile components [18, 19], the above solvation, hydrolysis, and substitution reactions become much more complicated and consequently cause the formation of a variety of aqueous metal complexes [20]. Although Pearson's acid-base classification system offers a general rule on complexing among metals and ligands [21], which species of aqueous metal complexes dominate the metal mobility and which factors control the stability of metal complexes under various hydrothermal conditions are still not clear. Over the past two decades, a large number of experimental studies on element or ore solubility [10-12] and in situ spectroscopy or synchrotron radiation measurements [14, 22], as well as molecular dynamics simulations [23-25], have remarkably enriched our knowledge of the nature and properties of the aqueous ore-forming metal complexes. A recent review by Brugger et al. [19] summarized the progress on the properties of ore-forming metal complexes in hydrothermal fluids. On one hand, however, previous studies have been mainly concerned about the metal complexes containing S, $\mathrm{Cl}$, carbon, or hydroxyl ligands and corresponding hard-acid metals. Little attention was paid to those metal complexes involving F, P, N, or organic ligands [19]. On the other hand, due to the limitations of in situ experimental devices, such as XANES, XAFS, and UV-Vis spectrophotometry, studies of metal complexing and speciation are mostly subject to low pressures (no more than several hundred bars) and low temperatures $\left(<400^{\circ} \mathrm{C}\right)$. In addition, molecular dynamics simulations prefer simple component systems. Hence the data on the nature and property of metal complexes under conditions analogous to natural hydrothermal fluids are indeed extremely sparse. Therefore, gaining more comprehensive data for the speciation and complexation of ore-forming metals adequately and using them for exploring the natural hydrothermal process will be a long-term task for the future.

Another challenge is to quantitatively evaluate the stability of metal complexes, which is important for understanding metal mobility and thus how many metals migrate in hydrothermal fluids (Figure 2). Although mineral solubility experiments have contributed a lot to the knowledge of metal mobility in hydrothermal fluids, the solubility data tell us more about the possible speciation and the maximum metal contents that the sources can supply (Figure 1) and much less about the stability of the metal complexes [26]. Given that the migration of ore-forming metal complexes is accompanied by its formation and hydrolysis [17, 27], the stability of metal complexes could be quantitatively characterized by the formation and hydrolysis constants of metal complexes, as shown in reactions (1) through (3). Also because the hydrolysis of metal complex usually induces the precipitation of metal [26], the hydrolysis behavior of metal complexes dictates how many metals migrate stably and for what distance (Figure 2). Although the hydrolysis of metal ions in aqueous solution has been studied at or near room temperature and atmospheric pressure for over 60 years $[28,29]$, the hydrolysis data on metal ions and particularly metal complexes at high temperature and high pressure are still scarce. This hinders us from quantitatively studying the mobility of metal complexes in hydrothermal fluids.

Besides, the hydrolysis of metal complexes in fluids is apparently a reverse process compared to the mineral dissolution. However, a few experimental studies between mineral solubility and metal-complex hydrolysis contain certain paradoxes. For example, rutile solubility in F-bearing hydrothermal solutions generally rises with increasing temperature $[30,31]$, promoting the formation of F-bearing Ti complexes. Nevertheless, the hydrolysis of a Ti fluoride complex in a hydrothermal solution, easily producing rutile mesocrystals and/or macrocrystals, also becomes intensified as the temperature increases [26]. The reason for this paradox is still obscure and awaits verification in the future.

\subsection{Element and Isotope Fractionation during Fluid-Rock} Interaction. Reactions of ore-forming fluids with the wall rock involve significant component exchanges and mineralogical and textural changes during the long flow or infiltration of the fluids (Figure 1). This process can result in not only the formation of broad alteration zones (i.e., greisenization and albitization) [1,32], but also the variation of the fluid's composition and $\mathrm{pH}$ values (Figure 2) [33], sometimes playing a decisive role on the formation of hydrothermal ore deposits [3].

During the fluid-rock interaction, two major pressing issues remain to be understood. The first one is element and isotopic fractionation during the process of disequilibrated fluid-flow reaction with the wall rock or the dissolution and precipitation of hydrothermal ore minerals. In recent years, nontraditional metal isotopes (i.e., $\mathrm{Fe}, \mathrm{Mg}, \mathrm{Ca}, \mathrm{Cu}, \mathrm{Zn}, \mathrm{Mo}$, 


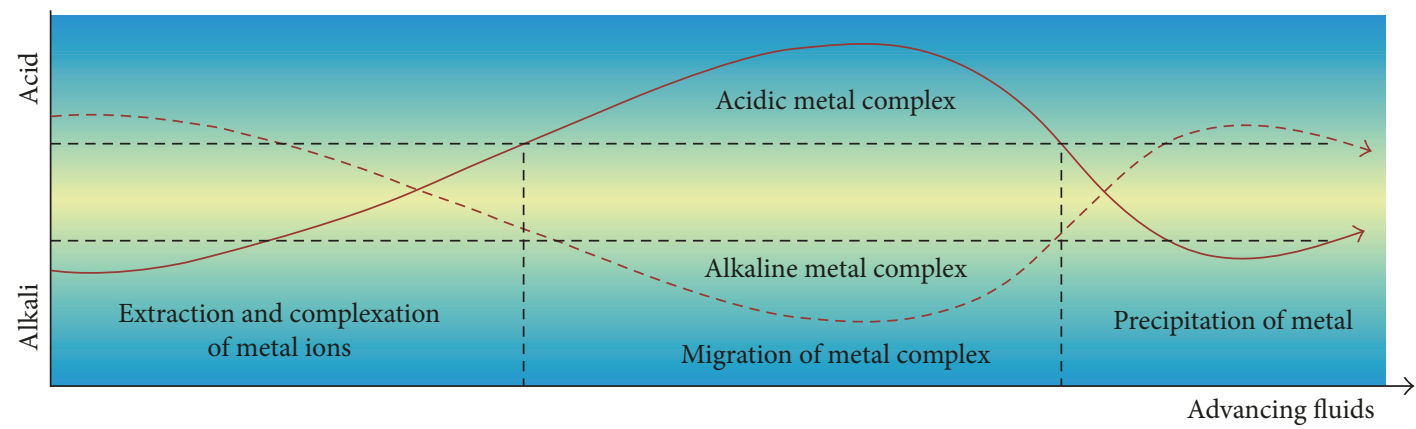

FIGURE 2: Schematic diagram on the formation, migration, and precipitation of metal complexes.

$\mathrm{Ti}$, and $\mathrm{Hg}$ ) have provided new powerful tools for tracing diverse geochemical processes. Because ore minerals are usually enriched in these metal elements, their dissolutionprecipitation processes in hydrothermal fluids can exhibit a significant influence on element and isotope fractionations [34]. However, related studies, particularly on the isotopic fractionation coefficients between ore mineral and fluids, are apparently rare. The lack of knowledge on the isotopic fractionations between metal-bearing phases and fluids prevents the accurate application of tracing the formation of magmatic or hydrothermal ore deposits.

The second issue concerns the vapor transport of oreforming metals during the fluid-rock interaction. The role of vapor transport in the formation of hydrothermal-related ore deposits has long been overlooked [16]. A few investigations have demonstrated that water vapor is capable of dissolving very high concentrations of ore-forming metals (i.e., $\mathrm{Cu}, \mathrm{Au}$, $\mathrm{Ag}$, and $\mathrm{Sn}$ ) [35] and can even cause $\mathrm{Cu}$ isotope fractionations [36]. Therefore, vapor-assisted metal transport and the resultant element/isotope fractionation may play a more important role during the compositional differentiation of magmatic-hydrothermal fluids and formation of hydrothermal ore deposits than has been previously recognized.

\subsection{Metal Precipitation and Growth of Ore Mineral. How} metal ore grows in hydrothermal fluids from a metal ion or metallic compound to the macrocrystals making up the ore is one of the most fundamental problems in mineralogy and metallogeny. Previous studies focused mainly on the factor controlling metal precipitation in hydrothermal fluids (i.e., temperature, $\mathrm{pH}$, and pressure) and the precipitation mechanisms (i.e., decreasing temperature or pressure, fluid mixing, fluid-water reaction, and decreasing oxygen fugacity) $[1,16,32]$. Other efforts have been attempted to establish the relationship between the form and morphology of the ore crystal and the surrounding environmental conditions [16]. These advances have considerably helped to improve our knowledge of the theory for hydrothermal metallogeny. However, the nucleation process and the kinetics of ore crystal growth in hydrothermal fluids are still less understood.

The growth of metal-bearing mineral in hydrothermal fluids generally experiences different stages from the micro to mesoscopic and finally to the macroscopic scale. Since 1990s, nanoscience and technology has highly promoted the development of functional materials. As the representatives of functional materials, the metal oxides and metal sulfides, as well as their morphologies and their growth mechanism, have been widely studied on the nanolevel $[37,38]$. These results do broaden our views and expand our knowledge of the growth of metal-bearing minerals, such that a new frontier interdisciplinary field is currently being developed, which combines nanoscience and metallogeny investigating the formation of hydrothermal ore deposits.

\section{Contents of the Special Issue}

Recent advances in high-temperature and high-pressure technology, combined with the development of experimental methods and pertinent analysis techniques, have considerably helped improve our knowledge concerning the oreforming metals and fluids under hydrothermal conditions. In particular, new studies have been made on synthesized or natural fluid inclusions using in situ analysis via laserablation inductively coupled plasma mass spectrometry. Additional techniques have utilized the visual hydrothermal cell, hydrothermal diamond-anvil cell, and fused silica capillary reactors, in combination with UV-Vis spectrophotometry, Raman spectroscopy, and synchrotron techniques. All these methods demonstrate a broad research perspective on hydrothermal processes.

The purpose of this special issue is to publish highquality research papers as well as review articles that seek to address recent advances on hydrothermal processes and metal mineral ore deposits. The 12 articles published here were chosen from 20 submissions, and most of them underwent two rounds of rigorous review. These contributions show the latest studied results on a variety of hydrothermal process and ore deposits. These include the Pacific Ocean, the Bamble Sector, S. E. Norway and the Massif Central, France in Europe, the Great Xing'an Range in the northeastern China, the Wutai-Hengshan region in the central North China Craton, the Nanling Mountains in South China, and finally the Tibetan Plateau, as well as various new experimental and analytical techniques, such as numerical simulations; observing mineral chemical reactions in fused silica glass tubes and the hydrothermal diamond-anvil cell with laser Raman confocal microscopy; LA-ICPMS analysis of fluid inclusions; and nontraditional stable isotopic methods. The 
contents of the published articles in this special issue can be roughly categorized as the evolution of hydrothermal fluids and their components (6 papers), the mineralogy and formation of hydrothermal ores (4 papers), and $\mathrm{Fe}-\mathrm{Cu}-\mathrm{Zn}$ isotopes of ores (2 papers).

\subsection{Evolution of Hydrothermal Fluids and Their Components.} The paper by A. K. Engvik et al. presents new data on stable isotopes from albite, scapolite, amphibole, quartz, and calcite mineral separates from metasomatised rocks in the Bamble lithotectonic domain, southeast Norway. These data increases our knowledge on the fluid type, source, and evolution during metamorphism. Their results support the interpretation that the original magmatic rocks were metasomatised by seawater solutions with possible involvement from magmatic fluids. The whole rock geochemistry records fluid mobilization and chemical transport, which supports a close relationship between metasomatism and mineral deposition.

Q. Shu and Y. Lai have studied fluid inclusions in quartz as well as the oxygen isotopic signature of the quartz from samples associated with early potassic alteration, synmineralization sericite-chlorite alteration, and postmineralization from the Haisugou porphyry Mo deposit, northern Xilamulun district, northeastern China. They demonstrate that the mixing of magmatic-hydrothermal fluids with meteoric water dominated the whole Mo mineralization process.

The paper by M. Harlaux et al. presents a complete study of primary fluid inclusions hosted in quartz and topaz from the Beauvoir rare-metal granite and the metasomatised stockwork (Massif Central, France). Based on microthermometry, Raman spectrometry, and laser-ablation inductively coupled plasma mass spectrometry of fluid inclusions, they found that the primary fluid inclusions preserve a pristine signature from the ore-forming fluids in both the Beauvoir granite and the associated metasomatised stockwork.

C. Konn et al. report the organic, gas, and element geochemistry from hydrothermal fluids of the newly discovered extensive hydrothermal area in the Wallis and Futuna region, SW Pacific. Geochemical research and estimates of heat fluxes suggest that back-arc hydrothermal activity contributes as much as the mid-ocean ridge system, and possibly more, which supports the idea that the hydrothermal contribution of back-arc environments is of great interest for the global ocean chemistry.

$\mathrm{S}$. Li et al. report microthermometric data from fluid inclusions in quartz and fluorite, as well as C-H-O-S isotope studies of quartz, from the Bairendaba $\mathrm{Ag}-\mathrm{Zn}-\mathrm{Pb}$ deposit, southern Great Xing'an Range, Northeast China. They demonstrate that the change in temperature, waterrock interaction, and fluid mixing caused metal precipitation from the ore-forming fluids. Being a typical mesothermal deposit, the Bairendaba deposit was formed in an extensional environment related to Early Cretaceous subduction of the Pacific Plate.

In a paper by $\mathrm{T}$. Liu et al., fluid inclusion and $\mathrm{C}-\mathrm{O}-\mathrm{S}-\mathrm{Pb}$ isotopic data from the Zhijiadi Ag- $\mathrm{Pb}-\mathrm{Zn}$ deposit, central North China, are reported. They find that the ore-forming fluids were derived from a magmatic system and strictly controlled by fault zones and conclude that the Zhijiadi Ag-Pb$\mathrm{Zn}$ deposit is a volcanic or subvolcanic-related hydrothermal deposit and not an epithermal one as previously predicted.

3.2. Mineralogy and Formation of Hydrothermal Ores. In the paper by Y. Wan et al., in situ Raman spectroscopy, quenched scanning electron microscopy, micro-X-ray diffraction, and thermodynamic calculations were used to explore the interplay between dolomite and silica-rich fluids at relatively low temperatures in fused silica glass tubes. The major contributions of this study are as follows: (1) the mechanism of talc mineralization in Mg-carbonate-hosted talc deposits is confirmed, and it is shown that talc can form at lower temperatures $\left(\leq 200^{\circ} \mathrm{C}\right)$ than previously documented; (2) the presence of talc in carbonate reservoirs can indicate the presence of a silica-rich hydrothermal fluid; and (3) the reactivity and solubility of silica require further consideration, when a fused silica glass tube is used as the reactor in high P-T experiments.

In the paper by J. Li and I.-M. Chou, in situ observations are reported concerning the processes of total homogenization of crystal-rich inclusions in spodumene from number 134 pegmatite dike, Jiajika deposit, China, using a new type of hydrothermal diamond-anvil cell (HDAC). These observations indicate that the minerals within the crystalrich inclusions were daughter minerals crystallized from an entrapped carbonate- and silica-rich aqueous solution at high temperature and, as such, provide useful information regarding the evaluation of granitic pegmatite formation models.

In the paper by X. Liu et al., finite element-based numerical experiments are used to investigate the influence of a hydraulic fracturing process on fluid flow and solubility of $\mathrm{CO}_{2}$ and quartz and aim to establish a link between fluid flow and wolframite mineralization. Their numerical experiments provide insight into the mechanisms precipitating wolframite in tungsten deposits from the Nanling Mountains, South China, and other metals whose solubility is strongly dependent on $\mathrm{pH}$.

$\mathrm{K}$. Hu et al. use a combination of microscopic work and electron probe microanalysis to characterize Au-hosting minerals and the form that Au takes in ore minerals from the Carlin-type Bojitian deposit, southwestern China. They find that the dominant minerals that host $\mathrm{Au}$ are arsenian pyrite and arsenopyrite, where Au occurs in the form of nanoscale $\mathrm{Au}^{0}$ and solid solution $\mathrm{Au}^{+}$. Consequently, they propose a new metallogenic model for the Bojitian Au deposit.

3.3. Fe-Cu-Zn Isotope of Ores. The paper by R. Mathur et al. collected and compiled the $\mathrm{Cu}$ isotope data from chalcocite according to three major sources, that is, supergene enrichment, sedimentary/red bed, and high-temperature hypogene mineralization. They find that chalcocites from these three major sources show distinct variations in $\mathrm{Cu}$ isotopic values, which are controlled by redox reactions at low-temperature and by equilibrium-type reactions at high temperature. This 
study demonstrates that the $\mathrm{Cu}$ isotope of chalcocite can be used to trace the genesis of the chalcocite.

In a paper by $\mathrm{D}$. Wang et al., electron microprobe analytical data and $\mathrm{Fe}-\mathrm{Zn}$ isotopic data are presented from sphalerite and carbonate samples from the Zhaxikang Sb-PbZn-Ag deposit, southern Tibet. They demonstrate that vaporliquid partitioning and mineral precipitation caused $\mathrm{Fe}-\mathrm{Zn}$ isotopic and other elemental variations. The genetic SEDEX model, modified by hydrothermal fluids, is the most plausible for this deposit.

Xing Ding
Daniel E. Harlov
Bin Chen
Weidong Sun

\section{References}

[1] F. Pirajno, Hydrothermal Mineral Deposits, Springer-Verlag, Berlin, Germany, 1992.

[2] M. J. Morales, R. C. Figueiredo e Silva, L. M. Lobato, S. D. Gomes, C. C. C. O. Gomes, and D. A. Banks, "Metal source and fluid-rock interaction in the Archean BIF-hosted Lamego gold mineralization: Microthermometric and LA-ICP-MS analyses of fluid inclusions in quartz veins, Rio das Velhas greenstone belt, Brazil," Ore Geology Reviews, vol. 72, no. 1, pp. 510-531, 2016.

[3] P. Lecumberri-Sanchez, R. Vieira, C. Heinrich, F. Pinto, and M. Wälle, "Fluid-rock interaction is decisive for the formation of tungsten deposits," Geology, vol. 45, no. 7, pp. 579-582, 2017.

[4] A. Audetat, D. Günther, and C. A. Heinrich, "Formation of a magmatic-hydrothermal ore deposit: Insights with LA-ICP-MS analysis of fluid inclusions," Science, vol. 279, no. 5359, pp. 20912094, 1998.

[5] J. J. Wilkinson, B. Stoffell, C. C. Wilkinson, T. E. Jeffries, and M. S. Appold, "Anomalously metal-rich fluids form hydrothermal ore deposits," Science, vol. 323, 2009.

[6] C-Y. Li, Y. H. Jiang, Y. Zhao, and et al., "Trace element analyses of fluid inclusions using laser ablation ICP-MS," Solid Earth Sciences, vol. 3, pp. 8-15, 2018.

[7] H. Keppler and P. J. Wyllie, "Partitioning of $\mathrm{Cu}, \mathrm{Sn}, \mathrm{Mo}, \mathrm{W}$, $\mathrm{U}$, and Th between melt and aqueous fluid in the systems haplogranite- $\mathrm{H}_{2} \mathrm{O}-\mathrm{HCl}$ and haplogranite- $\mathrm{H}_{2} \mathrm{O}-\mathrm{HF}$," Contributions to Mineralogy and Petrology, vol. 109, no. 2, pp. 139-150, 1991.

[8] D. E. Harlov and S. Melzer, "Experimental partitioning of Rb and $\mathrm{K}$ between phlogopite and a concentrated $(\mathrm{K}, \mathrm{Rb}) \mathrm{Cl}$ brine: Implications for the role of concentrated $\mathrm{KCl}$ brines in the depletion of $\mathrm{Rb}$ in phlogopite and the stability of phlogopite during charnockite genesis," Lithos, vol. 64, no. 1-2, pp. 15-28, 2002.

[9] P. Tropper and C. E. Manning, "Very low solubility of rutile in $\mathrm{H}_{2} \mathrm{O}$ at high pressure and temperature, and its implications for Ti mobility in subduction zones," American Mineralogist, vol. 90, no. 2-3, pp. 502-505, 2005.

[10] Q. Duc-Tin, A. Audétat, and H. Keppler, "Solubility of tin in $(\mathrm{Cl}, \mathrm{F})$-bearing aqueous fluids at $700{ }^{\circ} \mathrm{C}, 140 \mathrm{MPa}$ : A LAICP-MS study on synthetic fluid inclusions," Geochimica et Cosmochimica Acta, vol. 71, no. 13, pp. 3323-3335, 2007.

[11] T. Ulrich and J. Mavrogenes, "An experimental study of the solubility of molybdenum in $\mathrm{H} 2 \mathrm{O}$ and $\mathrm{KCl}-\mathrm{H} 2 \mathrm{O}$ solutions from $500^{\circ} \mathrm{C}$ to $800^{\circ} \mathrm{C}$, and 150 to $300 \mathrm{MPa}, "$ Geochimica et Cosmochimica Acta, vol. 72, no. 9, pp. 2316-2330, 2008.

[12] D. Dolejs and C. E. Manning, “Thermodynamic model for mineral solubility in aqueous fluids: Theory, calibration and application to model fluid-flow systems," Geofluids, vol. 10, no. 1-2, pp. 20-40, 2010.

[13] J. R. Taylor and V. J. Wall, "Cassiterite solubility, tin speciation, and transport in a magmatic aqueous phase," Economic Geology, vol. 88, no. 2, pp. 437-460, 1993.

[14] W. Liu, S. Borg, B. Etschmann, Y. Mei, and J. Brugger, "An XAS study of speciation and thermodynamic properties of aqueous zinc bromide complexes at $25-150^{\circ} \mathrm{C}$," Chemical Geology, vol. 298-299, pp. 57-69, 2012.

[15] G. Ottonello, Principles of Geochemistry, Columbia University Press, New York, NY, USA, 1997.

[16] H. L. Barnes, "Hydrothermal processes: The development of geochemical concepts in the latter half of the twentieth century," Geochemical Perspectives, vol. 4, no. 1, pp. I-93, 2015.

[17] J. Schott, O. S. Pokrovsky, and E. H. Oelkers, "The link between mineral dissolution/precipitation kinetics and solution chemistry," Reviews in Mineralogy and Geochemistry, vol. 70, pp. 207-258, 2009.

[18] T. M. Seward, A. E. Williams, and A. A. Migdisov, "The chemistry of metal transport and deposition by ore-forming hydrothermal fluids," in Treatise on Geochemistry, H. Holland and K. Turekian, Eds., pp. 29-57, 2nd edition, 2014.

[19] J. Brugger, W. Liu, B. Etschmann, Y. Mei, D. M. Sherman, and D. Testemale, "A review of the coordination chemistry of hydrothermal systems, or do coordination changes make ore deposits?" Chemical Geology, vol. 447, pp. 219-253, 2016.

[20] W. Grzybkowski, "Nature and properties of metal cations in aqueous solutions," Polish Journal of Environmental Studies, vol. 15, no. 4, pp. 655-663, 2006.

[21] R. G. Pearson, "Hard and soft acids and bases," Journal of the American Chemical Society, vol. 85, no. 22, pp. 3533-3539, 1963.

[22] P. J. Murphy and M. S. LaGrange, "Raman spectroscopy of gold chloro-hydroxy speciation in fluids at ambient temperature and pressure: A re-evaluation of the effects of $\mathrm{pH}$ and chloride concentration," Geochimica et Cosmochimica Acta, vol. 62, no. 21-22, pp. 3515-3526, 1998.

[23] R. J. Frick, A. B. Pribil, T. S. Hofer, B. R. Randolf, A. Bhattacharjee, and B. M. Rode, "Structure and dynamics of the $\mathrm{U}^{4+}$ ion in aqueous solution: An ab initio quantum mechanical charge field molecular dynamics study," Inorganic Chemistry, vol. 48, no. 9, pp. 3993-4002, 2009.

[24] X. Liu, X. Lu, R. Wang, H. Zhou, and S. Xu, "Speciation of gold in hydrosulphide-rich ore-forming fluids: Insights from first-principles molecular dynamics simulations," Geochimica et Cosmochimica Acta, vol. 75, no. 1, pp. 185-194, 2011.

[25] Y. Mei, D. M. Sherman, W. Liu, and J. Brugger, "Ab initio molecular dynamics simulation and free energy exploration of copper(I) complexation by chloride and bisulfide in hydrothermal fluids," Geochimica et Cosmochimica Acta, vol. 102, pp. 4564, 2013.

[26] J. He, X. Ding, Y. Wang, W. Sun, and B. Fu, "The effect of temperature and concentration on hydrolysis of fluorinerich titanium complexes in hydrothermal fluids: Constraints on titanium mobility in deep geological processes," Yanshi Xuebao/Acta Petrologica Sinica, vol. 31, no. 3, pp. 802-810, 2015.

[27] H. C. Helgeson, "Effects of complex formation in flowing fluids on the hydrothermal solubilities of minerals as a function of 
fluid pressure and temperature in the critical and supercritical regions of the system $\mathrm{H}_{2} \mathrm{O}$," Geochimica et Cosmochimica Acta, vol. 56, no. 8, pp. 3191-3207, 1992.

[28] C. F. Baes Jr. and R. F. Mesmer, "The thermodynamics of cation hydrolysis., American Journal of Science, vol. 281, no. 7, pp. 935962, 1981.

[29] D. R. Turner, M. Whitfield, and A. G. Dickson, "The equilibrium speciation of dissolved components in fresh water and seawater at $25^{\circ} \mathrm{C}$ and $1 \mathrm{~atm}$ pressure," Geochimica Et Cosmochimica Acta, vol. 45, pp. 855-881, 1981.

[30] J. F. Rapp, S. Klemme, I. B. Butler, and S. L. Harley, "Extremely high solubility of rutile in chloride and fluoride-bearing metamorphic fluids: An experimental investigation," Geology, vol. 38, no. 4, pp. 323-326, 2010.

[31] E. A. Tanis, A. Simon, Y. Zhang et al., "Rutile solubility in NaF-NaCl-KCl-bearing aqueous fluids at 0.5-2.79 GPa and 250$650^{\circ}$ C, 'Geochimica et Cosmochimica Acta, vol. 177, pp. 170-181, 2016.

[32] W. D. Sun, R. F. Huang, H. Li et al., "Porphyry deposits and oxidized magmas," Ore Geology Reviews, vol. 65, pp. 97-131, 2015.

[33] D. S. Korzhinsky, “The advancing wave of acidic components in ascending solutions and hydrothermal acid-base differentiation," Geochimica et Cosmochimica Acta, vol. 17, no. 1-2, pp. 1720, 1959.

[34] G. Saunier, G. S. Pokrovski, and F. Poitrasson, "First experimental determination of iron isotope fractionation between hematite and aqueous solution at hydrothermal conditions," Geochimica et Cosmochimica Acta, vol. 75, no. 21, pp. 66296654, 2011.

[35] A. E. Williams-Jones, A. A. Migdisov, S. M. Archibald Xiao, and Z. F. Xiao, "Vapor-transport of ore metals," in Water-rock interactions, ore deposits, and environmental geochemistry: A tribute to David A. Crerar, R. Hellmann and S. A. Wood, Eds., pp. 279-305, The Geochemical Society, 2002.

[36] K. U. Rempel, A. Liebscher, A. Meixner, R. L. Romer, and W. Heinrich, "An experimental study of the elemental and isotopic fractionation of copper between aqueous vapour and liquid to $450^{\circ} \mathrm{C}$ and 400bar in the CuCl-NaCl- $\mathrm{H}_{2} \mathrm{O}$ and $\mathrm{CuCl}-\mathrm{NaHS}-$ NaCl- $\mathrm{H}_{2} \mathrm{O}$ systems," Geochimica et Cosmochimica Acta, vol. 94, pp. 199-216, 2012.

[37] R. L. Penn and J. F. Banfield, "Morphology development and crystal growth in nanocrystalline aggregates under hydrothermal conditions: Insights from titania," Geochimica et Cosmochimica Acta, vol. 63, no. 10, pp. 1549-1557, 1999.

[38] F. Huang, H. Z. Zhang, and J. F. Banfield, “Two-stage crystalgrowth kinetics observed during hydrothermal coarsening of nanocrystalline ZnS," Nano Letters, vol. 3, pp. 373-378, 2003. 

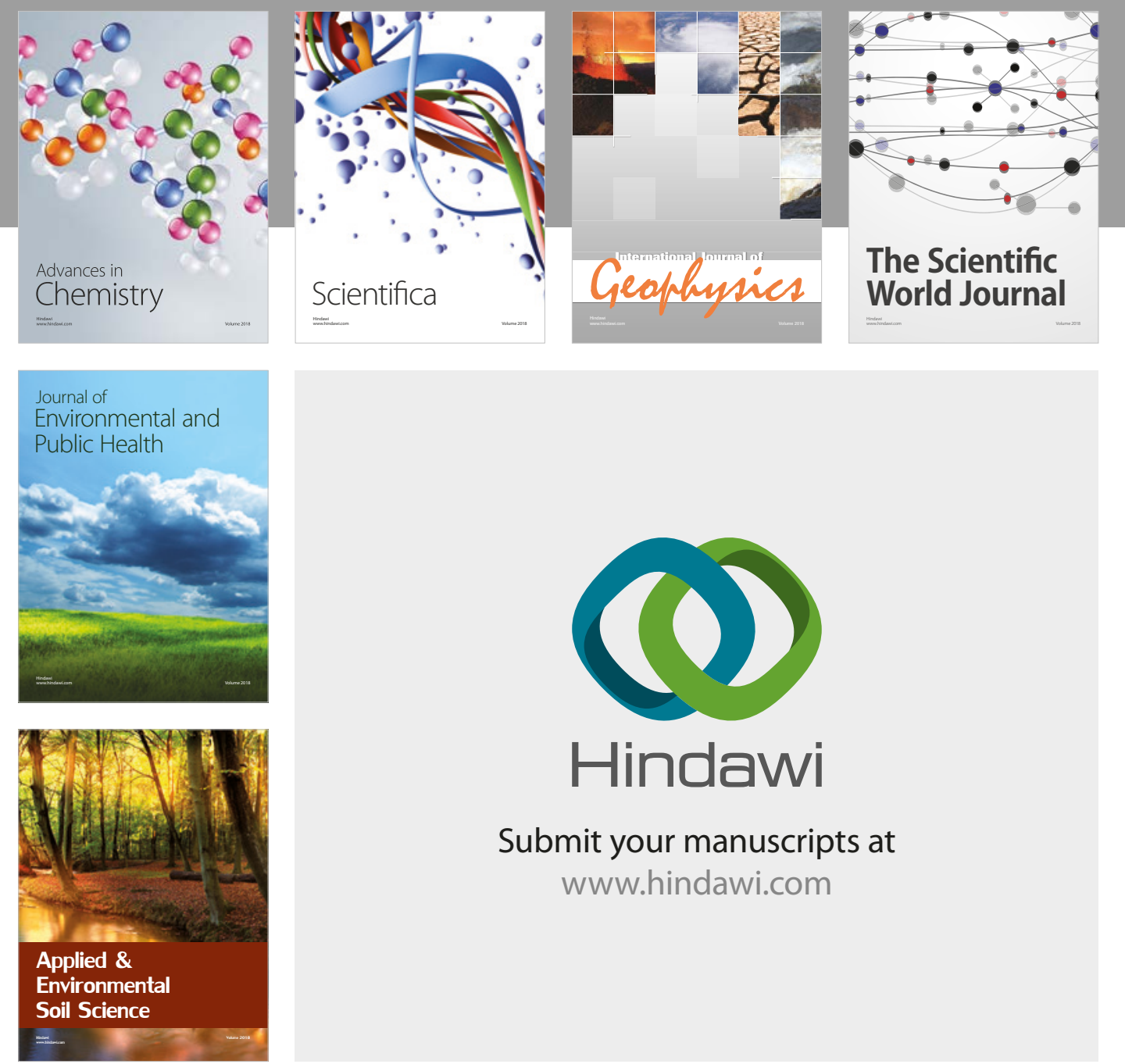

The Scientific

\section{World Journal}
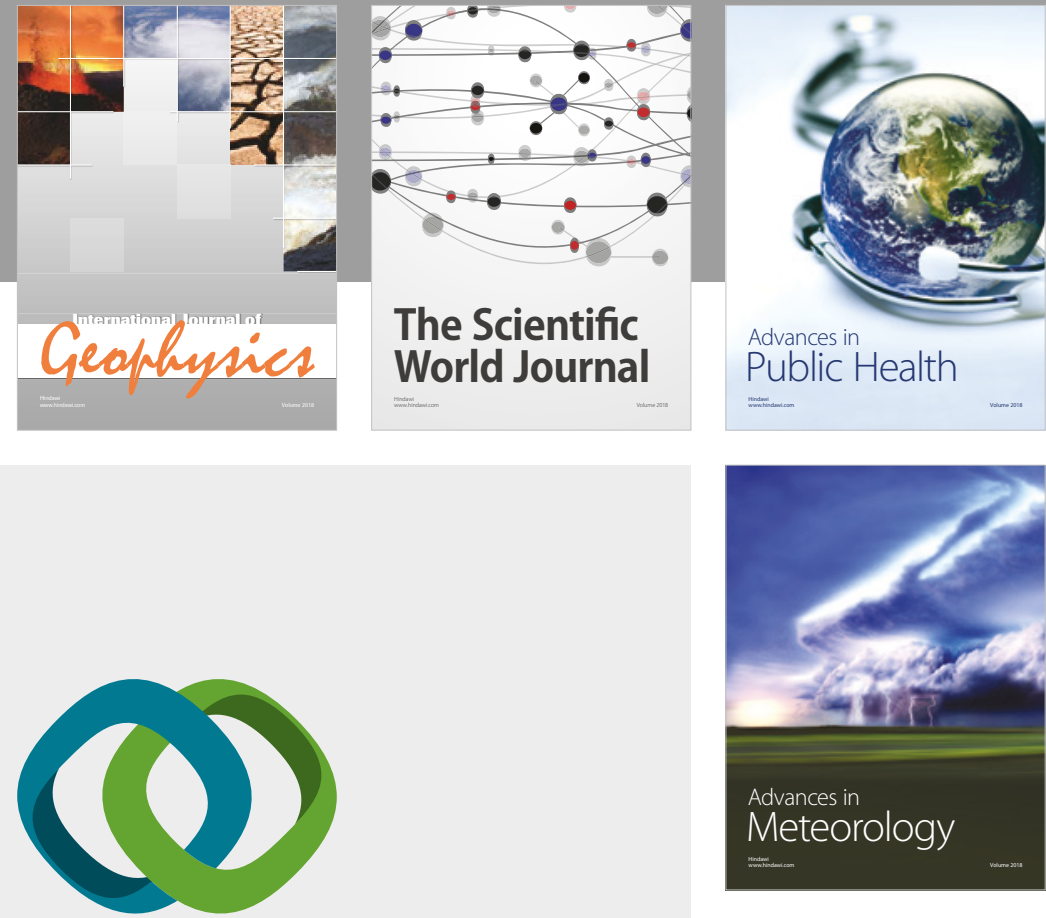

Advan

Public Health

\section{Hindawi}

Submit your manuscripts at

www.hindawi.com
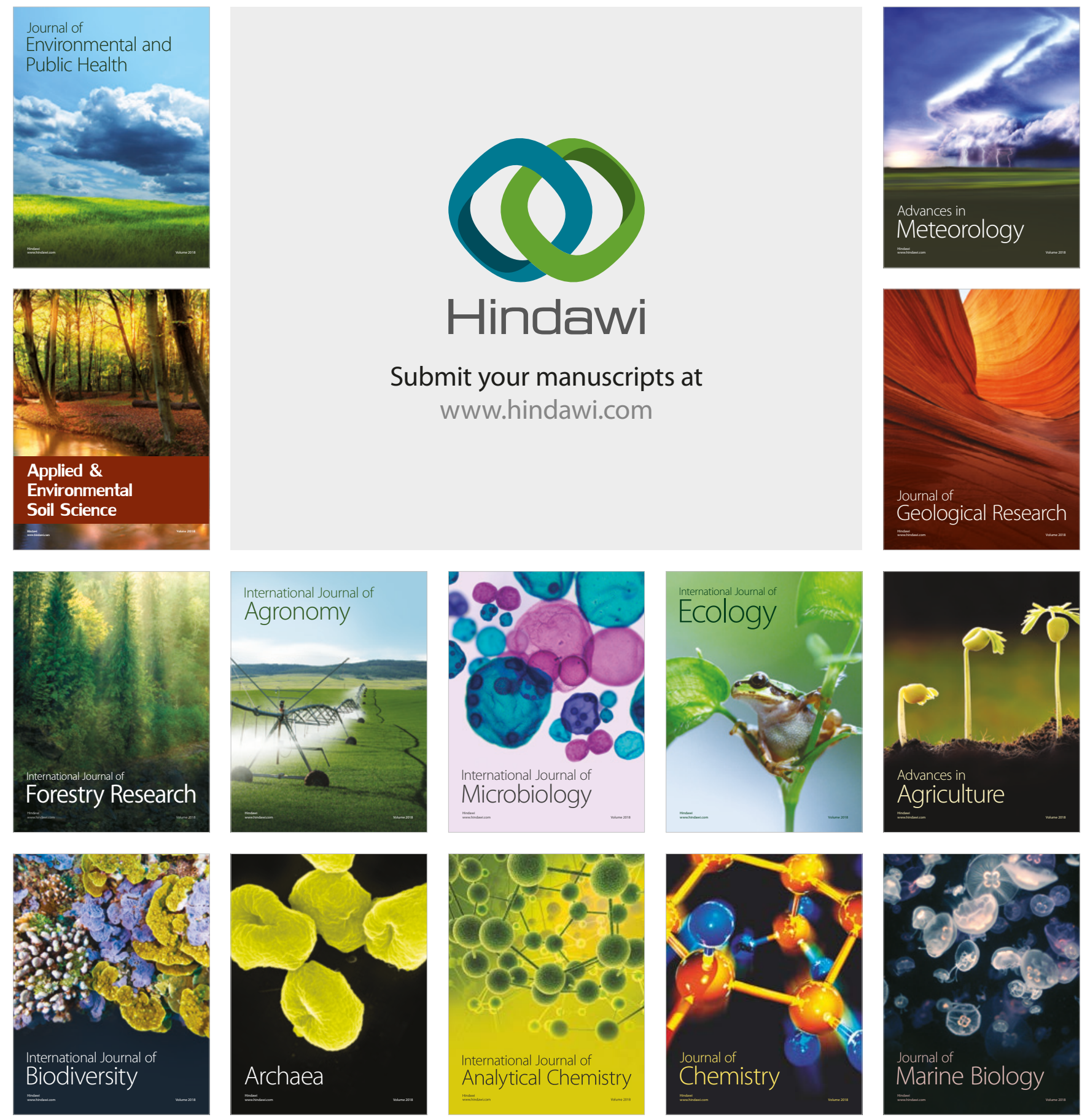